\title{
Kumara root resistance to Ceratocystis fimbriata
}

\author{
S.L. Lewthwaite ${ }^{1}$, P.J. Wright ${ }^{1}$ and C.M. Triggs ${ }^{2}$ \\ ${ }^{1}$ The New Zealand Institute for Plant \& Food Research Limited, Cronin Road, RD1, Pukekohe, \\ New Zealand \\ ${ }^{2}$ Department of Statistics, University of Auckland, Private Bag 92019, Auckland, New Zealand \\ Corresponding author: Steve.Lewthwaite@plantandfood.co.nz
}

The fungal pathogen Ceratocystis fimbriata causes a disease of the kumara (Ipomoea batatas or sweetpotato plant) known as black rot. The fungus was first recorded in New Zealand in 1907 and by 1947 black rot had become a significant problem for the kumara industry. The pathogen spread to most kumara production areas, causing severe or occasionally complete crop loss. The industry only survived this period by adopting strict hygiene practices, as the pathogen is highly transmissible. While the fungus may spread in propagation beds and within crops in the field, it is during storage and bulk handling of roots that most cross-infection occurs. Infection by C. fimbriata may stimulate the kumara root to respond by producing phytoalexins, which are toxic and bitter in taste. Although there have been no reports of human poisoning, there have been cattle deaths as a direct consequence of consumption of infected kumara roots. One approach to limiting disease spread is through using resistant cultivars. A laboratory bioassay was developed to distinguish levels of cultivar storage root resistance to C. fimbriata infection. The traditional and modern cultivars assessed showed a range $(\mathrm{P}<0.001)$ of responses to pathogen infection by point inoculation.

\section{Viral infection of the kumara crop}

\author{
S.L. Lewthwaite ${ }^{1}$ and J.D. Fletcher ${ }^{2}$
}

1The New Zealand Institute for Plant \& Food Research Limited, Cronin Road, RD1, Pukekohe, New Zealand

2The New Zealand Institute for Plant \& Food Research Limited, Private Bag 4704, Christchurch, New Zealand

Corresponding author: Steve.Lewthwaite@plantandfood.co.nz

Viral infection within the New Zealand kumara (Ipomoea batatas) or sweetpotato crop has not been considered an important production issue until recent times. The visual symptoms of viral infection may be quite inconspicuous. The general presence of 'Sweetpotato viruses' was formally acknowledged in 1989, based on published literature. New Zealand's first extensive kumara crop virus survey was published in 2000. Using nitrocellulose membrane ELISA, this survey detected the presence of Cucumber mosaic virus (CMV), virus C-6, Sweetpotato caulimo-like virus (SPCaLV), Sweetpotato chlorotic fleck virus (SPCFV or C-2), Sweetpotato feathery mottle virus (SPFMV), Sweetpotato latent virus (SwPLV), Sweetpotato mild mottle virus (SPMMV) and Sweetpotato mild speckling virus (SPMSV, formerly C-8). Sweetpotato virus $G$ (SPVG) was first identified within New Zealand kumara in 2005. A second comprehensive crop survey, using real-time reverse transcription PCR, was published in 2009. This survey revealed a virus previously undetected in New Zealand, Sweetpotato virus 2 (SPV2). International research and subsequent commercial experience with virus-tested propagation systems has shown the potential for economically significant yield and quality gains. The local industry has started examining the benefits of kumara virus elimination within the New Zealand biophysical production environment. 